\title{
A 14-year-old girl with thoracolumbar pain
}

\author{
Maryam Haddadzadeh \\ Ahvaz Jundishapur University of Medical Sciences, Ahvaz, Iran \\ Kardiochirurgia i Torakochirurgia Polska 2014; 11 (1): 83-85
}

\begin{abstract}
We report the second case of Mycobacterium kansasii spondylitis in a 14-year-old Caucasian girl who presented with pain in the thoracolumbar region. There was collapsed T8 and discitis, and a cavitary lesion in new chest CT. Biopsy taken from thoracic lesion T8 with CT guidance which had evidence of osteomyelitis and its smear were negative for acid fast bacilli. Bronchoalveolar lavage (BAL) was performed - PCR was negative for acid fast bacilli. Empirical treatment of tuberculosis started and her symptoms resolved. PCR of thoracic sampling revealed $M$. kansasii after one month. Two months after treatment of $M$. kansasii, her thoracolumbar pain resolved and the cavitary lesion of the lung disappeared. In patients who are immunocompromised in the association of cavitary pulmonary lesion and infectious spondylitis, atypical mycobacteria may be on the list of common clinical diagnoses but not in immunocompetent patients such as our patient.

Key words: Mycobacterium kansasii, spondylitis, immunocompetent.
\end{abstract}

\section{Introduction}

Mycobacterium kansasii is a non-tuberculosis mycobacterium that is more prevalent in southeastern and southern coastal states and the central plains [1]. Most of the patients (69.3\%) are HIV positive. Chronic diseases were common among HIV-negative persons; however, $40.3 \%$ had no predisposing medical condition [2]. Mycobacterium kansasii usually presents as lung disease in which the most common radiologic presentation is cavitation of the lung parenchyma [3-5]. Involvement of the musculoskeletal system occurs in approximately $5-10 \%$ of patients with atypical mycobacterial infection [6]. We report a 14-year-old immunocompetent girl who presented with $M$. kansasii spondylitis.

\section{Streszczenie}

W pracy zaprezentowano drugi w literaturze przypadek zapalenia kręgów spowodowany prątkami Mycobacterium kansasii. Pacjentka rasy kaukaskiej, lat 14, zgłosiła się z bólem w okolicy piersiowo-lędźwiowej. Badanie tomografii komputerowej (TK) klatki piersiowej uwidoczniło zapaść w rejonie T8, infekcję przestrzeni międzykręgowej oraz zmianę jamistą. Wykonano biopsję zmiany piersiowej T8 pod kontrolą TK, która wykazała przesłanki dla zdiagnozowania zapalenia szpiku i kości; rozmaz nie wykazał obecności prątków kwasoopornych. Wykonano płukanie oskrzelowo-płucne (bronchoalveolar lavage - BAL); test PCR (polymerase chain reaction) nie wykazał obecności prątków kwasoopornych. Wdrożono leczenie empiryczne gruźlicy, które zniosło objawy. Po miesiącu test PCR przeprowadzony na próbkach z klatki piersiowej wykazał obecność M. kansasii. Dwa miesiące po wdrożeniu leczenia M. kansasii ból w okolicy piersiowo-lędźwiowej ustał, a jamista zmiana w płucu zaniknęła. Prątki atypowe mogą się znajdować na liście typowych rozpoznań klinicznych u pacjentów z obniżoną odpornością w związku z jamistymi zmianami w płucach oraz infekcyjnym zapaleniem kręgów, ale nie u pacjentów immunokompetentnych, takich jak opisana pacjentka.

Słowa kluczowe: Mycobacterium kansasii, zapalenie kręgów, immunokompetencja.

\section{Case report}

The patient was a 14-year-old girl who presented with thoraco-lumbar pain over a one-year period. She had no fever, cough, or arthralgia. The thoraco-lumbar MRI revealed a collapsed T8 vertebral body and discitis of T8-9. Chest CT scan showed pulmonary nodules in the left lung upper lobe (Fig. 1). Vertebral body CT guidance biopsy showed no pathologic findings. The pulmonary nodules were not reachable. After one year she referred to hospital for aggravated pain.

The patient's vital signs were normal. Head and neck were normal. Chest examination revealed tenderness in the thoracolumbar region with no other abnormality. The abdomen was soft without organomegaly. No clubbing or

Address for correspondence: Assistant Prof. Maryam Haddadzadeh, Ahvaz Jundishapur University of Medical Sciences, Imam Khomeini Hospital, 61357 Ahvaz, Iran, phone: 00986112921839 , e-mail: m.haddadzadeh_sh@yahoo.com 


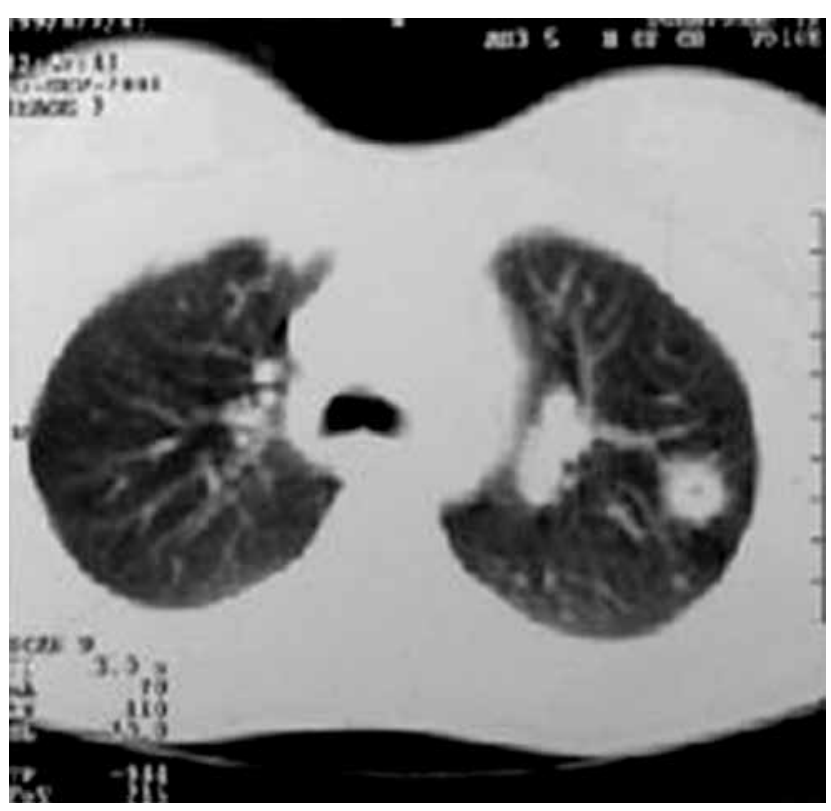

Fig. 1. Nodules in left upper lobe

edema was found on her extremities. Neurologic examination was normal.

A hemogram revealed hemoglobin of $11 \mathrm{~g} / \mathrm{dl}$, total leukocyte count of $11.3 \times 10^{3}$ ( $80 \%$ neutrophils), and normal platelet count. Blood chemistry and urine analysis were normal. Levels of immunoglobulin were in the normal range and the HIV test was negative. A CT scan of the chest showed a cavitary lesion in the left lung upper lobe (Fig. 2). Recent MRI showed paravertebral fluid collection other than previous findings.

Bronchoscopy was performed. Acid fast bacilli were not found in BAL fluid study. Para-vertebral fluid collection was sampled and a biopsy was obtained from T8 (Fig. 3). Evidence of osteomyelitis was found in the biopsy (Fig. 4).

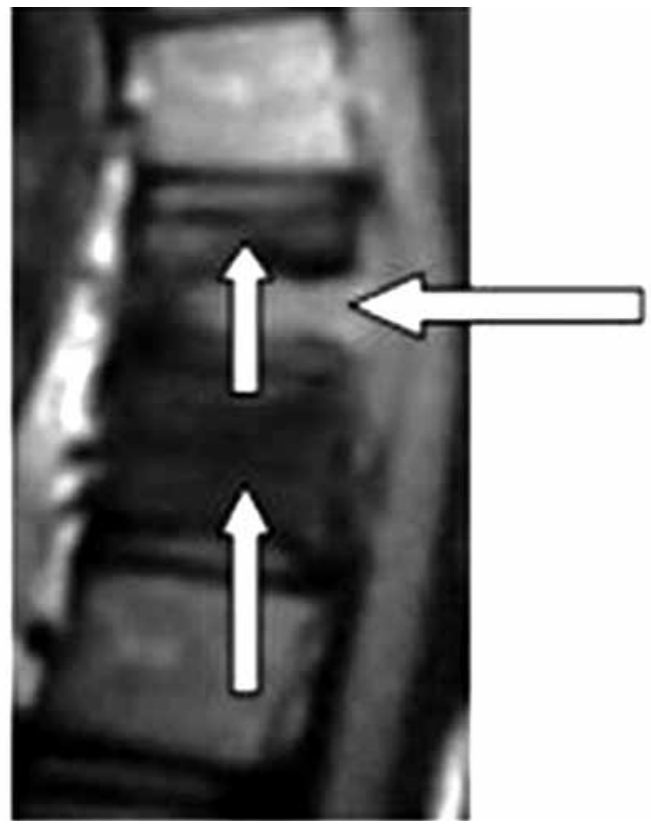

Fig. 3. Collapse of T8 (upper vertical arrow) and extending abscess (horizontal arrow) and osteopenia in T9 (lower vertical arrow)

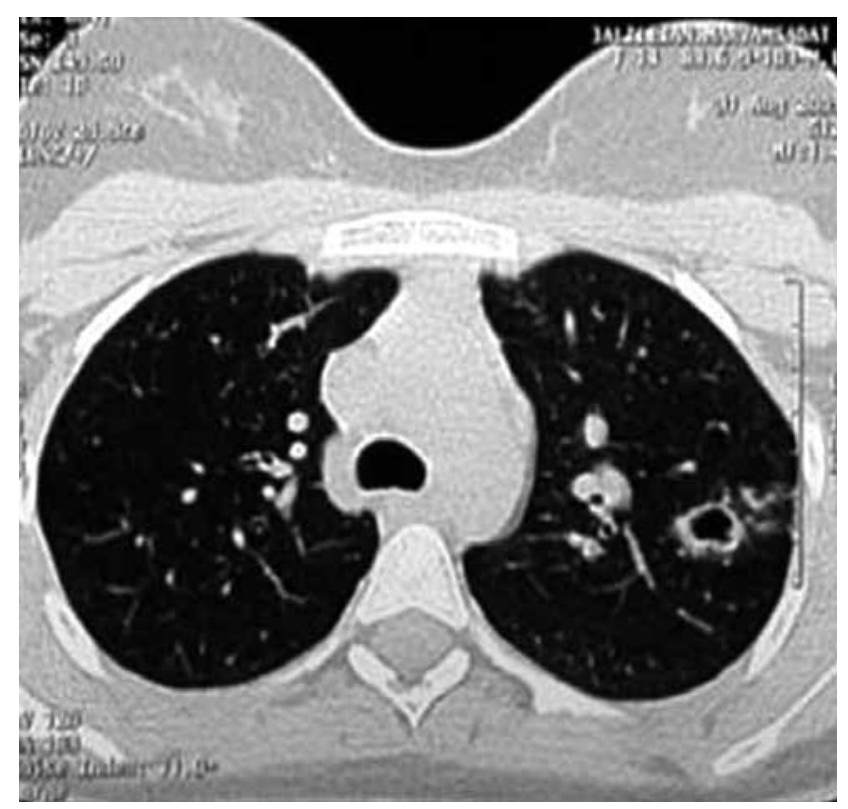

Fig. 2. Cavity in left upper lobe

PCR of purulent material collection in the paravertebral region for mycobacterium tuberculosis was negative. One month later, PCR of culture of fluid collection of this region was positive for M. kansasii.

We treated the patient with isoniazid, rifampin, and ethambutol for 18 months. Her thoracolumbar pain resoIved after about two months, ESR decreased and the pulmonary lesion disappeared. We followed the patient for about two years without relapse of her symptoms.

\section{Discussion}

We found only two reports of $M$. kansasii spondylitis in an immunocompetent patient $[7,8]$. In patients with myco-

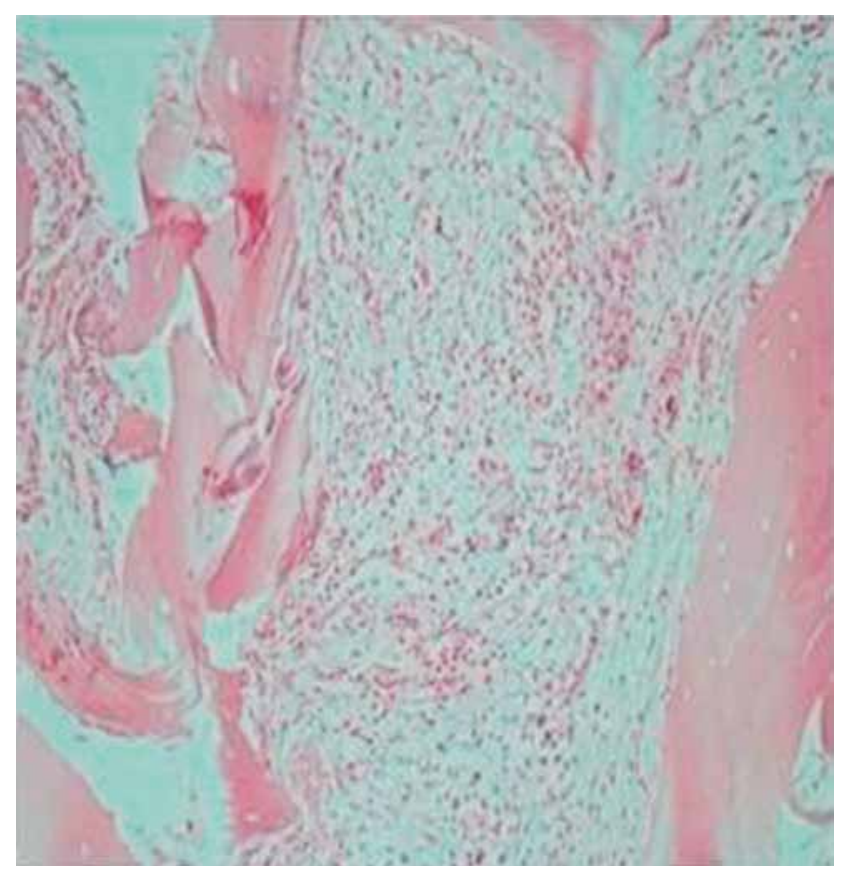

Fig. 4. Infiltration of inflammatory cells in vertebrae 
bacterial spondylitis, local tenderness, pain, and limitation of spinal mobility are the presenting symptoms, whereas constitutional symptoms such as fever, malaise, and weight loss may also occur. The radiologic manifestations of spine osteomyelitis are involvement of one or several contiguous vertebral bodies; destruction of the intervening disks; absence of reactive sclerosis; and formation of soft-tissue abscesses [9].

The diagnostic criteria to support non-tuberculous mycobacterium (NTM) clinical infection as opposed to colonization of secretions include one of the following: positive culture results from at least two separate expectorated sputum samples (regardless of AFB smear result) or positive culture result from at least one bronchial wash or lavage (regardless of AFB smear result) or transbronchial or other lung biopsy with mycobacterial histopathological features (granulomatous inflammation or AFB) and positive culture for NTM or biopsy showing mycobacterial histopathological features (granulomatous inflammation or AFB) and one or more sputum or bronchial washings that are culture positive for NTM or a positive culture from pleural fluid or any other normally sterile extrapulmonary site.

The American Thoracic Society recommendation for treatment of this infection consists of a three-drug combination consisting of isoniazid (300 $\mathrm{mg}$ daily), rifampin (600 mg daily), and ethambutol (15 mg/kg per day). The duration of treatment is 12 to 24 months [10].

\section{Implications for physicians}

Our case was the third case of $M$. kansasii spondylitis in an immunocompetent patient in the reported cases that we could find in the literature. Because of the rarity of the disease in immunocompetent patients her diagnosis was delayed, so we suggest including $M$. kansasii infection in the differential diagnosis of immunocompetent patients with clinical findings similar to tuberculosis.

\section{References}

1. Chapman J. The Atypical Mycobacteria. Plenum Publishing, New York 1977.

2. Bloch KC, Zwerling L, Pletcher MJ, Hahn JA, Gerberding JL, Ostroff SM, Vugia DJ, Reingold AL. Incidence and clinical implications of isolation of Mycobacterium kansasii: results of a 5-year, population-based study. Ann Intern Med 1998; 129: 698-704

3. Ahn CH, McLarty JW, Ahn SS, Ahn SI, Hurst GA. Diagnostic criteria for pulmonary disease caused by Mycobacterium kansasii and Mycobacterium intracellulare. Am Rev Respir Dis 1982; 125: 388-391.

4. Johanson WG Jr, Nicholson DP. Pulmonary disease due to Mycobacterium kansasii. An analysis of some factors affecting prognosis. Am Rev Respir Dis 1969; 99: 73-85.

5. Christensen EE, Dietz GW, Ahn CH, Chapman JS, Murry RC, Hurst GA. Radiographic manifestations of pulmonary Mycobacterium kansasii infections. Am J Roentgenol 1978; 131: 985-993.

6. Department of Health. Tuberculous notifications in New South Wales 1989. New South Wales, Australia: Department of Health, 1989. State Health Publication 89-086.

7. Masahiro W, Yoshimasa O, Daisuke I, Naoko S. A Case of Spondylitis Due to Atypical Mycobacterium. Orthopedics \& Traumatology 1999; 48: 824-828.

8. Watanakunakorn C, Trott A. Vertebral osteomyelitis due to Mycobacterium kansasii. The American review of respiratory disease. Am Rev Respir Dis 1973; 107: 846-850.

9. Theodorou DJ, Theodorou SJ, Kakitsubata Y, Sartoris D, Resnick D. Imaging characteristics and epidemiologic features of atypical mycobacterial Infections Involving the musculoskeletal system. Am J Roentgenol 2001; 176: 341-349.

10. Griffith DE, Aksamit T, Brown-Elliott BA, Catanzaro A, Daley C, Gordin F, Holland SM, Horsburgh R, Huitt G, lademarco MF, Iseman M, Olivier K, Ruoss S, von Reyn CF, Wallace RJ Jr, Winthrop K; ATS Mycobacterial Diseases Subcommittee; American Thoracic Society; Infectious Disease Society of America. An official ATS/IDSA statement: diagnosis, treatment, and prevention of nontuberculous mycobacterial diseases. Am J Respir Crit Care Med 2007; 175: 367-416. 